\title{
ע Tieto, tapahtuma ja sukupuoli HPV-rokotteen kehystyminen rokoteikäisillä tytöillä ja kouluterveydenhoitajilla
}

Tarkastelemme terveyssosiologisessa artikkelissamme sitä, miten HPV-rokote kehystyy suomalaisten rokoteikäisten tyttöjen arjessa ja kouluterveydenhoitajien työssä. Tutkimusaineistomme koostuu 2I kouluterveydenhoitajan ja 12 rokoteikäisen tytön teemahaastatteluista. Taustoittavana aineistona hyödynnämme virallisen Tyttöjen juttu -rokotekampanjan materiaaleja. Analyysimme rakentuu aineistolähtöisesti. Hyödynnämme sen taustana monipaikkaisen kehystymistutkimuksen tutkimustapaa ja tutkimustavassa keskeistä kehystymisen käsitettä. Tarkastelemme terveydenhoitajien ja tyttöjen rokotekehystymisiä tiedollisella, sosiaalisella ja sukupuolen ulottuvuudella. Peilaamme kehystymisiä myös toisiaan vasten ja paikannamme niiden väliltä sekä kitkoja että jatkuvuuksia. Rinnastamme kehystymisiä edelleen virallisen rokotekampanjan tietopainotteisiin rokotekehyksiin. Tuloksina esitämme, että HPV-rokote kehystyy rokoteikäisille tytöille ensisijaisesti sukupuolittuneena, heidän omaa ikäryhmäänsä koskettavana tapahtumana, jonka keskiössä on neulalla pistäminen. Tytöillä ei ole välttämättä halua, tarvetta tai resursseja rokotekampanjassa korostuvaan tiedolliseen pohdintaan ja tietoperustaiseen päätöksentekoon. He keskustelevat rokotteesta sosiaalisissa suhteissaan, mutta varsinaisessa päätöksenteossa korostuu erityisesti äidin mielipide. Kouluterveydenhoitajille rokote kehystyy puolestaan osana käytännöllistä, kouluissa tehtävää terveystyötä. Terveydenhoitajat pohtivat lisäksi tyttöjen kypsyyttä rokotemekanismin ymmärtämiseen ja itsenäisen rokottamispäätöksen tekemiseen. Johtopäätöksenä nostamme esille kehystymisten välisen kitkan. Tyttöjen ja terveydenhoitajien rokotekehystymiset eivät asetu suoraan järkevää yksilöllistä päätöksentekoa painottavaan kampanjakehykseen, mikä haastaa terveystieteellistä lähtökohtaa tietoperustaisesta suostumuksesta. Kouluterveydenhoitajat käsittelevät kitkaa käytännön työssään. He välittävät virallisen rokotekampanjan tietopohjaista kehystä ja tyttöjen omia rokotekehystymisiä. Tiedon jakamisen sijasta keskeistä on saavuttaa rokottamisrutiini kiireisen arjen keskellä ja säilyttää luottamuksellinen suhde tyttöihin ja heidän vanhempiinsa.

ASIASANAT: HPV-rokote, rokoteikäiset tytöt, kouluterveydenhoitajat, rokotekampanja, kehystyminen, terveyssosiologia

MIKKO J. VIRTANEN, SAARA SALMIVAARA 


\section{YDINASIAT}

- Suomen virallisessa, Tyttöjen jutuksi nimetyssä HPV-rokotekampanjassa sukupuolittunut rokotekehys voimaannuttaa tyttöjä erityisenä ryhmänä. Pinkki sukupuolittuneisuus ei kuitenkaan asetu kampanjan keskeiseksi kehykseksi vaan pikemminkin kutsuu tyttöjä pohtimaan rokotetta tiedollisesti ja tekemään yksilöllisesti järkevän rokotuspäätöksen. Tiedollinen, järkevän rokotetoimijuuden kehys on kampanjassa keskeinen.

- HPV-rokote ei kuitenkaan kehysty rokoteikäisille tytöille ensisijaisesti tiedolliseksi kysymykseksi, vaan sukupuolittuneeksi tapahtumaksi ja neulalla olkavarteen pistämiseksi.

- Tytöille rokotteen sukupuolittuneisuus on luonnollistunutta. Toisin kuin Tyttöjen juttu -kampanjassa, sukupuolittuneisuus ei johda rokotejärkeilyyn vaan pikemminkin estää rokotetta ja sen vaikutusmekanismia koskevan ymmärryksen muodostumista. Rokote kehystyykin tytöille tarkemmin jäsentymättömäksi naisten syöpärokotteeksi.
- Kouluterveydenhoitajat huolehtivat rokottamisen käytännöistä. He myös välittävät virallisen rokotekampanjan kehyksiä ja tyttöjen omia rokotekehystymisiä: terveyden edistämistä sekä siihen kytkeytyvää järkevää yksilötoimijuutta ja tytöille keskeisiä erityisen tapahtuman ja pistämisen merkityksiä.

- Terveydenhoitajat tasapainoilevat virallisen rokotetiedon jakamisen ja tyttöjen sekä heidän vanhempiensa moninaisten rokotenäkemysten ymmärtävän huomioimisen välillä. Sosiaalisesti rakentuva ja ylläpidetty luottamus tyttöihin ja heidän vanhempiinsa ovat heille yhtä lailla tärkeitä kuin rokotetiedon jakaminen. HPV-rokote on tässä kontekstissa vain yksittäinen tapahtuma vuosia kestävässä, kotien kanssa yhteistyössä toteutettavassa terveystyön jatkumossa, eikä siihen liittyvien kysymysten kannata antaa rapauttaa tärkeää luottamussuhdetta.

\section{JOHDANTO}

Rokotteiden määrä ja merkitys terveydenhuollossa kasvaa jatkuvasti. Vaikka rokotteista puhutaan usein yhtenä ryhmänä, on niillä enemmän eroja kuin yhtäläisyyksiä (1). Suomen kansalliseen rokotusohjelmaan vuonna 2013 otettu HPV-rokote on yhteiskunnallisesti erityisen mielenkiintoinen. Tutkimuksen toteuttamishetkellä rokote annetaan ensinnäkin sukupuoleltaan ja iältään erityiselle ikäryhmälle, 10-12-vuotiaille tytöille. Rokotteen saa ilmaiseksi kouluterveydenhuollossa, ja se annetaan kahtena pistoksena lähtökohtaisesti viidennellä ja kuudennella luokalla. Halukkaille rokotetta tarjotaan ilmaiseksi koko peruskoulun ajan. THL on suosittanut HPV-rokotetta myös osaksi poikien rokotusohjelmaa, ja rokotteen antaminen pojille on mainittu vuoden 2019 hallitusohjelmassa (2). Pojat otettiin lopulta rokotteen piiriin tämän artikkelin kirjoittamisen jälkeen 23.3.2020. Kysymys siitä, missä määrin lapsuudesta varhaisnuoruuteen siirtymässä olevat 10-12-vuotiaat ovat tiedollisesti kykeneviä päättämään omaa terveyttään koskevista asioista, on yhteiskunnallisesti tärkeä ja tutkimuksellisesti mielenkiintoinen. Kysymyksen merkitystä lisää se, ettei vanhempien erillistä suostumusta rokottamiseen ole enää vuoden 2019 syksystä alkaen vaadittu.
Sukupuolittuneisuuden ja ikäryhmän lisäksi HPV-rokotteen erityispiirteenä on sen viimekätinen kohde, kohdunkaulan syöpä. Kyseessä on ensimmäinen rokote, jonka ensisijaisena tarkoituksena on syövän ehkäisy. Kohdun kaulaosan syöpätapauksia todetaan Suomessa vuosittain keskimäärin noin 170 kappaletta, ja näistä keskimäärin joka kolmas johtaa kuolemaan. Syöpää ehkäistään rokotteen lisäksi verrattain kattavalla papa-seulonnalla (2) ja enenevissä määrin myös HPV-testiin perustuvalla seulonnalla.

HPV-rokotteen nimi tulee sanoista human papillomavirus. Tarkalleen ottaen rokote annetaan syövän kehittymiseen yhteydessä olevien tiettyjen seksiteitse tarttuvien papilloomavirustyyppien torjumiseksi. Toisin kuin kohdunkaulan syöpä, papilloomavirus on erittäin yleinen. Globaalisti yli kolme neljästä ihmisestä saa virustartunnan, mutta yli 90 prosenttia tartunnoista paranee itsestään eikä aiheuta oireita. Lisäksi virustartunnalle altistuvat kaikki sukupuolet. Kohdunkaulan syövän lisäksi tietyt papilloomavirustyypit ovat yhteydessä myös muihin syöpiin, kuten nielurisan, emättimen, peniksen ja peräaukon syöpiin (2). Kolmas HPV-rokotteen erityispiirre liittyykin seksiin: rokotteen tautiopillisena kohteena 
ovat tietyt seksin välityksellä tarttuvat papilloomavirustyypit. Rokote pyritään näin ollen antamaan hyvissä ajoin ennen seksielämän aloittamista, mutta kuitenkin niin, että sen vaikutus ulottuisi mahdollisimman pitkään tytön elämässä. HPV-rokote yhdistää sukupuolen, erityisen ikäryhmän ja seksin toisiinsa.

Erityinen, sukupuolittunut kohderyhmä ja seksi yhdistyvät kulttuurisesti erityisen pelottavaksi mielletyn sairauden, syövän, ennaltaehkäisyyn. HPV-rokotteen syöpää ehkäisevästä vaikutuksesta ja Suomen yleisesti verrattain korkeasta rokotuskattavuudesta huolimatta ennakoitua useampi on kieltäytynyt rokotteesta. Vuoden 2020 alussa rokoteikäisten ikäluokkien HPV-rokotuskattavuus oli noin 70 prosenttia ja alueelliset erot olivat merkittäviä (2). Kansalliseksi tavoitteeksi on asetettu 80 prosentin kattavuus, ja esimerkiksi Ruotsissa kattavuus vastaavana ajankohtana oli 85 prosenttia $(2,3)$.

Vaikka HPV-rokotteen immunologiset vaikutukset ovat biologisia, toteutuvat ne vain, jos päättää ottaa rokotteen. Näin ollen tutkimusten tulisi huomioida myös rokotepäätöksen taustalla olevat sosiaaliset ja kulttuuriset tekijät (4). Otamme tämän haasteen vastaan ja pureudumme tässä artikkelissa HPV-rokotteen sosiokulttuuriseen merkitykselliseksi muodostumiseen. Emme tarjoa kuitenkaan ensisijaisesti selityksiä HPV-rokotteesta kieltäytymiselle. Sen sijaan tarkastelemme rokotetta laadullisen terveyssosiologian näkökulmasta. Mainitut neljä toisiinsa yhdistyvää HPV-rokotteen erityispiirrettä - verrattain matala rokotuskattavuus, erityinen ja sukupuolittunut kohderyhmä, seksi ja syöpä - toimivat tarkastelumme lähtökohtina. Tässä raamissa kiinnostuksen kohteenamme on se, miten rokote, rokottaminen ja rokotuspäätös kytkeytyvät osaksi rokotteeseen liittyvien ryhmien elämää. Tarkastelumme kohteena ovat rokoteikäiset tytöt ja rokottamisesta vastaavat kouluterveydenhoitajat. Pureudumme siihen, miten HPV-rokote muodostuu merkitykselliseksi tyttöjen jokapäiväisessä elämässä ja kouluterveydenhoitajien päivittäisessä työssä. Tarkastelemme näitä rokotteen merkitykselliseksi muodostumisen prosesseja kehystymisinä (framings). Peilaamme myös tyttöjen ja kouluterveydenhoitajien rokotekehystymisiä toisiaan vasten. Nostamme esille erityisesti tietoon, sosiaalisiin suhteisiin ja sukupuoleen liittyviä kitkoja ja jatkuvuuksia.
Käymme seuraavassa läpi HPV-rokotetta koskevaa terveys- ja sosiaalitieteellistä tutkimusta ja esitämme oman tutkimusasetelmamme. Tämän jälkeen esittelemme aineistomme ja menetelmämme sekä kuvaamme analyysityötämme. Artikkelin seuraava osio kattaa puolestaan tekemämme analyysin ja sen tulokset. Päätämme tarkastelumme analyysin tulosten pohjalta avautuvaan keskusteluun.

\section{KATSAUS TUTKIMUSKENTTÄÄN}

Rokotteet ylipäänsä, ja HPV-rokote erityisesti, ovat nousseet tärkeiksi tutkimusaiheiksi paitsi lääketieteen eri tutkimusaloilla ja terveystieteissä, myös terveyssosiologiassa $(5,6)$. Terveystieteellisten tutkimusten yleisenä tavoitteena on terveyden edistäminen rokotekattavuutta parantamalla. Tästä näkökulmasta rokotuspäätökseen keskeisesti vaikuttaviksi tekijöiksi on nostettu ensinnäkin äidin ja tyttären välinen vuorovaikutus $(7,8,9)$. Toiseksi on korostettu rokotetiedon, ennakkoluulojen, asenteiden ja luottamuksen merkitystä päätöksenteossa, sekä tytöillä että heidän vanhemmillaan (10-16). Myös terveydenhuollon ammattihenkilöstön tiedot ja asenteet on nostettu esille rokotuspäätökseen vaikuttavina tekijöinä (17-20). Tältä pohjalta on korostettu virallisen rokotetiedon jakamisen sekä tietoon pohjautuvan suosittelun roolia rokotuskattavuuden nostamisessa (21-23).

Tutkimusten toteutustavoissa ja tulosten tulkinnassa korostuu tietoisen rokotuspäätöksen asetelma ja tähän yhdistyvä niin sanottu tietovajemalli $(24,25)$. Mallilla viitataan ajattelutapaan, jonka mukaan HPV-rokotekattavuus paranisi, jos erityisesti tytöt ja heidän vanhempansa sekä myös terveydenhuollon ammattihenkilöt tietäisivät rokotteesta, sen terveysvaikutuksista ja riskien minimaalisuudesta enemmän. Jos virallista, tutkittua rokotetietoa olisi tehokkaammin saatavilla esimerkiksi kouluterveydenhoitajien kautta koteihin, rokotteen ottaisi nykyistä useampi.

Terveyssosiologiset HPV-rokotetutkimukset pohjautuvat puolestaan yksilöä laajempaan näkökulmaan. Tiedollisen rokotuspäätöksen ja järkeilevän yksilön sijasta tutkimuksissa on pureuduttu niihin tapoihin, joilla rokotekampanjoissa tuotetaan järkeilevää yksilötoimijuutta. Samalla painopiste siirtyy yksilöistä sosiokulttuurisiin tekijöihin. HPV-rokotetta tarkastellaan esimerkiksi osana rokotteeseen liittyvien ryhmien arkielämää. Terveyssosiologisten näkökulmien kautta 
aukeaa myös kriittinen, erityisesti piiloiseen valtaan ja hallintaan pureutuva näköala rokotteeseen ja rokotekampanjoihin.

Terveyssosiologisille lähtökohdille rakentuvissa tutkimuksissa on ensinnäkin tarkasteltu rokotteiden vakiinnuttamista kansallisiin rokotusohjelmiin ja valotettu taloudellisten, tieteellisten, oikeudellisten ja poliittisen prosessien ja järkeilytyylien yhteenkietoutumisia näissä prosesseissa. Tutkimukset osoittavat, ettei rokotteita oteta käyttöön puhtaan lääketieteellisin kriteerein, eivätkä lääketieteelliset kriteerit ole ristiriidattomia (2630). Toiseksi biopoliittisen hallinnan ja rokotteen sukupuolittuneisuuden aspektit on nostettu keskeisiksi. HPV-rokotekampanjat tuottavat riskaabelia tyttöyttä, jota hallitaan väestöllisesti: Kampanjat pohjautuvat epidemiologiseen riskijärkeilyyn, joka yhdistyy terveyskäytäntöjen sukupuolittuneisuuteen ja kiinnittyy ylisukupolviseen, sukupuolittuneeseen hoivaan. Nuorten, terveiden tyttöjen elämään tuodaan vakavan syöpäsairauden riski, jolta rokote sekä siihen yhdistyvä, äitien affektuaalinen ja vastuullinen hoiva suojaavat (31-35). Samalla rokotteen hallinnallisuus yhdistyy ruumiillisuuteen: syöpäriskin vähentäminen rokottamalla asettaa tytön elämän farmakologisesti hallittavaksi hänen kehonsa ja sitä uhkaavan riskin kautta (36-41).

\section{TUTKIMUSASETELMA}

Osallistumme HPV-rokotetta koskevaan tutkimuskeskusteluun nostamalle esille rokotteen erilaisia sosiokulttuurisia merkityksiä kahdessa keskeisessä sijainnissa: osana rokoteikäisten tyttöjen elämää ja kouluterveydenhoitajien arkea. Tarkastelemme rokotemerkitysten muodostumista kehystymisen käsitteen avulla. Peilaamme näitä kehystymisiä paitsi toisiaan vasten, myös virallisen Tyttöjen juttu -rokotekampanjan keskeisiin rokotekehyksiin. Paikannamme lopuksi peilausten pohjalta jatkuvuuksia ja kitkoja eri kehystymisten välillä.

Tutkimuksemme metodologinen tausta on monipaikkaisessa kehystymistutkimuksessa (MKT; 42, 43). Erving Goffmanin, Ian Hackingin ja Michel Callonin käsitteitä sekä kulttuurisosiologisia ja tieteen ja teknologian tutkimuksen aineksia yhdistelevä tutkimustapa opastaa havainnoimaan HPV-rokotteen tyyppisiä ilmiöitä monipaikkaisesti. Ilmiöt yhtäältä muodostuvat eri sijainneissa havaittavien kehystymisten yhteenliittymiksi. Toisaalta rokotteen kaltaiset ilmiöt välittävät niitä kehystymisiä, joita eri sijainneissa tapahtuu. Tutkimustapaan sisältyy kriittistä potentiaalia, sillä välittymistä ei tarkastella neutraalina ja symmetrisenä: yhdessä sijainnissa vakiintuneet kehystymiset koettelevat toisen sijainnin kehystymisiä, ja tähän koetteluun usein myös pyritään. Esimerkiksi rokotekampanjassa keskeisiä ja suhteellisen vakiintuneita kehyksiä pyritään aktiivisesti levittämään, jotta ne muokkaisivat kouluterveydenhoitajien ja rokoteikäisten tyttöjen rokotekehystymisiä.

Teemme aineistolähtöistä analyysiä MKT:n viitekehyksessä ja hyödynnämme aineistopohjaisten löydöstemme tulkinnassa kehystymisen käsitettä. MKT:ssa keskeinen, Erving Goffmanilta peräisin oleva kehystyminen (framing; 44) viittaa merkityksen muodostumiseen:HPV-rokote kehystyy tietyllä tavalla merkitykselliseksi tietyssä kontekstissa tapahtuvassa sosiaalisessa toiminnassa. Seuraamme MKT:n prosessuaalista Goffmantulkintaa: kyse ei ole yksilötoimijan kehystämistyöstä eikä rakenteellisista kehyksistä vaan sosiokulttuurisesta kehystymisen prosessista, jossa yksilön aktiivinen merkityksenanto ja rakenteelliset tekijät käyvät yhteen $(42,43)$. Kehyksistä puhumme ainoastaan silloin, kun kehystyminen on selkeästi vakautunut.

Virallinen HPV-rokotekampanja kantaa, pitää yllä ja levittää tietynlaista rokotekehystä, joka ilmenee kampanjamateriaaleissa, julkilausumissa ja tiedotteissa sekä rokotuskoulutusten sisällöissä. Tarkastelumme kriittinen potentiaali nousee monipaikkaisuuden operationalisoinnista. Nostamme esille vakautuneen kampanjakehyksen ohella - ja sille vastapainoksi - kahden keskeisesti HPV-rokotteeseen liittyvän ryhmän, rokoteikäisten tyttöjen ja kouluterveydenhoitajien omaa rokotetoimijuutta, joka ilmenee kummankin ryhmän rokotekehystymisten kautta. Tuomme näin ollen kuuluviin tietopohjaista päätöksentekoa painottavassa rokotekeskustelussa katveeseen jääneitä tyttöjen oman elämän ja terveydenhoitajien työkäytäntöjen ääniä.

Lähdemme liikkeelle kysymällä, miten HPVrokote kehystyy osana rokoteikäisten tyttöjen elämää ja suomalaisten kouluterveydenhoitajien käytännön työssä. Jaamme kehystymisten analyysimme aineistopohjaisesti tiedon, sosiaalisten suhteiden ja sukupuolen ulottuvuuksille. Peilaamme kummallekin ryhmälle keskeisiä rokotekehystymisiä toisiaan vasten näillä ulottuvuuk- 
silla ja paikannamme kehystymisten väliltä sekä kitkoja että jatkuvuuksia. Tarkastelemme kouluterveydenhoitajien ja tyttöjen kehystymisiä myös suhteessa THL:n toteuttaman Tyttöjen juttu -kampanjan rokotekehyksiin.

\section{AINEISTOT, MENETELMÄT JA ANALYYSITYÖ}

Tavoitteenamme ei ole esittää yleistettävissä olevia väitteitä HPV-rokotteesta ja rokottamisesta Suomessa, sillä aineistomme eivät muodosta edustavaa otosta kohderyhmiemme rokotetta koskevista näkemyksistä. Sen sijaan pureudumme siihen, miten HPV-rokote tulee merkitykselliseksi rokotteen kannalta keskeisissä ryhmissä. Tarkastelumme pureutuu näin ollen tyttöjen rokotetta koskevan pohdinnan ja kouluterveydenhoitajien rokottamistyön uppoutuneisuuteen osaksi kummankin ryhmän elämää ja tuottaa terveyssosiologisen puheenvuoron ajankohtaiseen, tietopohjaisen päätöksenteon hallitsemaan rokotekeskusteluun, jossa tyttöjen ja terveydenhoitajien omat äänet ovat jääneet katveeseen. Hyödynnämme monipuolista laadullista tutkimusaineistoa täyttääksemme tutkimustehtävämme.

Aineistokorpuksemme koostuu ensisijaisesta, haastattelupohjaisesta aineistosta ja taustoittavasta aineistosta. Ensisijainen aineistomme kattaa kouluterveydenhoitajien (A1) ja rokoteikäisten tyttöjen (A2) puolistrukturoidut teemahaastattelut. A1 koostuu 21 kouluterveydenhoitajan ja kolmen työharjoittelussa olevan terveydenhoitajaopiskelijan haastatteluista ( 16 yksilö- ja neljä parihaastattelua). Parihaastatteluista kolmessa toinen haastateltava oli terveydenhoitajaopiskelija ja yhdessä kumpikin haastateltava työskenteli kouluterveydenhoitajana. Kaikki haastateltavat olivat naisia, iältään 20 ja 68 ikävuoden välissä. Haastattelut tehtiin eteläisen Suomen alueella syksyn 2019 aikana. Haastatteluista 19 tehtiin kouluterveydenhoitajan työtiloissa ja kaksi muussa tilassa. Haastattelujen kestot vaihtelivat 50 minuutista 97 minuuttiin ja tyypillisin kesto oli tunti kymmenen minuuttia. Haastatteluteemat koostuivat ensinnäkin rokotetiedosta ja tiedottamisesta, rokottamiskäytännöistä ja rokottamisen haasteista ja toiseksi tyttöjen rokotetietoa koskevista näkemyksistä sekä tyttöjen ja heidän vanhempiensa rokotteeseen suhtautumisen pohdinnasta. Haastateltavilla oli kokonaisuutena laaja kokemus rokottamisesta. He toimivat tai olivat toimineet erilaisissa, eri kokoisissa ja eri alueilla sijait- sevissa kouluissa. Suurin osa oli työskennellyt kouluterveydenhoitajana koko sen ajan, kun HPV-rokotteita on Suomessa annettu eli vuodesta 2013 lähtien. Terveydenhoitajaopiskelijat toivat haastatteluihin puolestaan juuri valmistumassa olevien näkökulman. Haastatteluaineisto osoittautui kokonaisuutena erittäin rikkaaksi ja tarjoaa mahdollisuuden pureutua kouluterveydenhoitajien rokotekehystymisiin syvällisesti ja monipuolisesti.

A2 käsittää puolestaan kahdentoista rokotusikäisen tytön haastattelut (kymmenen yksilö- ja yksi parihaastattelu). Haastattelut kerättiin pirkanmaalaisissa peruskouluissa vuoden 2018 aikana ja toteutettiin tyttöjen kotiluokissa. Kaikki haastateltavat olivat kuudesluokkalaisia ja kaikki olivat ottaneet rokotteen. Haastattelurunko koostui kolmesta teemasta. Ensimmäisessä pyrittiin tavoittamaan rokotteen yleisiä merkityksiä, toisessa rokotteen ja sen ottamisen sosiaalisia ulottuvuuksia ja kolmannessa sukupuoleen ja seksuaalisuuteen liittyviä kysymyksiä. Tytöille haastavan aiheen vuoksi haastattelut olivat kestoltaan lyhyitä, noin kymmenestä reiluun kahteenkymmeneen minuuttiin. Parihaastattelun kesto oli 27 minuuttia. Haastattelut osoittautuivat kuitenkin tiheiksi ja sisällöllisesti rikkaiksi ja mahdollistavat näin ollen tutkimustehtävämme toteuttamisen.

Aineistojen keruussa noudatettiin tarkasti ihmistieteiden tutkimuseettisiä periaatteita. Haastateltavat tytöt rekrytoitiin koulujen kautta. Haastatteluista sovittiin ensin koulujen kanssa ja tutkimuksesta tiedotettiin haastateltaville ja heidän vanhemmilleen opettajien kautta. Samalla tarjottiin mahdollisuus kysyä lisätietoja sekä pyydettiin haastateltavilta ja heidän vanhemmiltaan kirjallinen lupa osallistua tutkimukseen. Virallinen tutkimuslupa anottiin kunnasta, jossa haastattelut tehtiin. Tässä yhteydessä pohdittiin myös erillisen eettisen ennakkoarvioinnin tarpeellisuutta kunnan tutkimusluvista vastaavan terveydenhuollon asiantuntijan kanssa. Arvioinnille ei kuitenkaan nähty erityistä syytä. Kouluterveydenhoitajien työorganisaatioilta anottiin puolestaan ensin viralliset tutkimusluvat. Tässä yhteydessä oltiin yhteydessä heidän esimiehiinsä, joille avattiin tutkimuksen taustaa ja käytäntöjä. Tutkimusluvan saamisen jälkeen ja esimiesten hyväksyttyä tutkimuskäytännön terveydenhoitajia lähestyttiin suoraan haastattelukutsulla. 
Kaikille haastateltaville kerrottiin tutkimuksesta, sen käytännöistä ja siihen osallistumisen vapaaehtoisuudesta. Haastatteluvaiheessa varmistettiin haastateltavan suostumus haastatteluun ja kerrottiin mahdollisuudesta keskeyttää haastattelu ja ilmoittaa, ettei haastattelumateriaalia saa hyödyntää tutkimuksessa. Lisäksi tyttöjen haastattelut ajoitettiin rokottamisen jälkeiseen aikaan, jotta tutkimukseen osallistuminen ei vaikuttanut rokotuspäätökseen, ja sensitiivisen aiheen vuoksi haastattelutilanteiden eettiseen toteutukseen kiinnitettiin erityistä huomiota. Kaikki haastattelut äänitettiin ja litteroitiin ja niistä tehtiin muistiinpanoja haastatteluhetkellä ja välittömästi sen jälkeen. Haastattelumateriaalit pseudonymisoitiin litterointivaiheessa ja tunnistettavuuden mahdollistavat tiedot poistettiin.

Kouluterveydenhoitajien ja rokoteikäisten tyttöjen haastatteluaineistojen lisäksi hyödynnämme tutkimuksemme taustana vuonna 2016 aloitettua, toisen kirjoittajista toteuttamaa kenttätyötä, jonka tavoitteena on ollut kartoittaa HPV-rokotteen ympärille muodostuvia verkostoja, paikantaa keskeisiä toimijoita ja tutkimussijainteja sekä pureutua rokotteen ja rokotetutkimuksen taustaan. Tässä yhteydessä meille keskeinen on aineisto-osio, joka kattaa Tyttöjen juttu -kampanjan tekstuaaliset ja visuaaliset suunnittelu- ja kampanjamateriaalit. Aineiston analyysityö on kuvattu toisessa yhteydessä (44).

Analysoimme rokoteikäisten tyttöjen aineiston ensin. Jotta pääsimme pureutumaan mahdollisimman tarkasti haastateltujen omiin rokotetta koskeviin käsityksiin ja ymmärryksiin, hyödynsimme analyysissä grounded theory -menetelmää (GT, 45) mukailevaa aineistolähtöistä sisällönanalyysiä. Analyysi toteutettiin ATLAS. ti-ohjelmalla ja se aloitettiin koodaamalla kolme haastattelua yhden puheenvuoron (virkkeen tai virkeparin) tarkkuudella ja käyttämällä ensisijaisesti aineistosta sellaisenaan löytyviä in vivo -koodeja. Tämän jälkeen koodeista muodostettiin aineistoon peilaamisen ja koodien välisen vertailun pohjalta koodiryhmiä. Näillä koodiryhmillä koodattiin edelleen koko aineisto. Samalla palattiin tarvittaessa täydentämään alkuperäisiä koodeja ja niiden pohjalta muodostettuja koodiryhmiä. Osaa alkuperäisistä koodeista hyödynnettiin itsenäisinä koodiryhminä eli osalla alkuperäiskoodeista koodattiin koko aineisto. Lopuksi koodiryhmien pohjalta analysoitiin esille teemoja ja edelleen abstraktimman tason kategorioita.

Myös kouluterveydenhoitajien haastattelut analysoitiin Atlaksella. Analyysi toteutettiin teoriaohjautuvan sisällönanalyysin periaatteita noudattaen. Koska koko analyysityön tavoitteena oli tulkita tyttöjen ja terveydenhoitajien rokotekehystymisiä toisiaan vasten, käytettiin analyysityötä ohjaavana aineksena tyttöjen haastatteluiden analyysissä muodostettuja teemoja. Näitä teemoja peilattiin myös aiemmin toteutetussa rokotekampanjan analyysissä esille nousseisiin rokotekehyksiin (44). Tältä pohjalta pureuduimme analyysissämme siihen, miten rokote kehystyy tiedon, sosiaalisten suhteiden ja sukupuolen ulottuvuuksilla. Koska tyttöjen näkemysten analyysi tehtiin ensin, voitiin kouluterveydenhoitajia koskevaa analyysiä suunnata hoitajien ja tyttöjen kehystymisten väliin, kehystymisissä ilmeneviin eroihin ja yhtäläisyyksiin.

Esittelemme seuraavassa analyysimme kouluterveydenhoitajien (A1) ja rokoteikäisten tyttöjen (A2) haastatteluiden yhdistelmänä ja nostamme tältä pohjalta esille tyttöjen ja terveydenhoitajien rokotekehystymisten kitkoja ja jatkuvuuksia. Peilaamme kehystymisiä myös rokotekampanjan keskeisiin kehyksiin. Jaottelemme analyysimme kahteen osioon, tietoon ja sosiaalisiin kehystymisiin pureutuvaan. Sukupuoli nousi analyysissämme keskeiseksi sekä tietoa että sosiaalisia suhteita jäsentäväksi kategoriaksi, joten käsittelemme sitä kummankin osion sisällä.

\section{ANALYYSI JA TULOKSET}

Tyttöjen juttu -rokotekampanjaa jäsentävät keskeisesti kaksi rokotekehystä: 1) tiedollinen, yksilön järkevää päätöksentekoa korostava sekä 2) sukupuolittunut, tyttöjä erityisenä ryhmänä puhutteleva ja samalla heitä voimaannuttava (44). Kehykset kietoutuvat asymmetrisesti yhteen: sukupuolittunut ja voimaannuttava kehys on alisteinen tietopohjaiselle kehykselle. Sosiaalisesti tiheä, erityinen tyttöys, jota kampanjan pinkki yleisilme korostaa, toimii rokotekampanjan ydinviestin välittäjänä ja suostuttelee tutustumaan siihen. Kampanjan ydinviesti on tietoon perustuva, yksilölle järkevä päätös. Rokotekampanjan kansanterveydellistä tavoitetta, väestöllisen laumasuojan muodostumista, tavoitellaan omasta terveydestään huolehtivien tyttöjen tietopohjaisten päätösten summana. Samalla kampanja tuottaa yksilöllisesti 
järkevää terveyskansalaisuutta. Kutsumme kampanjassa keskeistä, väestöllisen tavoitteen ja tiedollisen yksilöjärkeilyn yhdistävää rokotekehystä järkevän rokotetoimijuuden kehykseksi.

\section{TIETO}

Kouluterveydenhoitajat toimivat kouluissa terveydenhuollon ammattilaisina. He saavat HPVrokotetta koskevaa tietoa ensisijaisesti THL:n koulutusmateriaaleista. Virallinen rokotetieto sekä siihen tukeutuva terveydenedistämistyö jäsentävät heidän käytännön toimintaansa ja ammatillista itseymmärrystään. Terveydenhoitajat eivät kuitenkaan juurruta suoraviivaisesti virallisessa rokotekampanjassa keskeistä, järkevän rokotetoimijuuden kehystä tyttöjen elämään. HPV-rokote kehystyy hoitajille pikemminkin rokottamisena, joka asettuu osaksi kouluissa tehtävää monipuolista terveydenhoitotyötä; terveyden edistämisen julkilausuttu tavoite asettuu osaksi terveydenhoitajien arkea ensisijaisesti rokottamisen konkreettisena järjestämisenä.

Haastattelija: "Miten oot työssäsi tekemisissä tän HPV-rokotteen kanssa?”

Titta, A1: "Käytännön työssä...osana tätä terveyden edistämistä."

Terveydenedistämiseen kuuluu myös tiedon jakamista, mutta ennen kaikkea kyse on arkisesta rokotteiden tilaamisesta ja niiden säilytyksestä huolehtimisesta, tyttöjen ja vanhempien informoimisesta rokottamiskäytännöistä sekä rokotteiden pistämisestä ja rokotetietojen kirjaamisesta. Tätä työtä tehdään kontekstissa, jossa työtehtävät lisääntyvät ja rokottamiseen liittyvät ohjeistukset vaihtuvat tiheästi.

HPV-rokote ei kehysty myöskään rokoteikäisille tytöille lähtökohtaisesti tiedolliseksi kysymykseksi. Sen sijaan rokote merkitsee ensisijaisesti kokemuksellisuutta ja tapahtumallisuutta, jonka keskiössä on neulalla pistäminen. Tyttöjä pistetään ja pistäminen saattaa jännittää, pelottaa ja aiheuttaa sivuoireita, jotka häiritsevät välitöntä arkea, kuten harrastuksiin osallistumista.

Maria, A2: "Sen käden nostaminen ni se vähän sattu...ni onneks mä otin sen kuitenki vasempaan käteen, joka oli hyvä, mutta mä en sit voinu mennä reeneihin mut se oli vaan se yks päivä.”
Vaikka rokotteeseen ja rokotuspäätökseen liittyy paljon monimutkaisia kysymyksiä, tytöt kysyvät terveydenhoitajilta selvästi eniten juuri pistämisestä. "Kysymykset mä sanoisin et 99 prosenttisesti liittyy kipuun. [...] Ne pelkää sitä et miltä se tuntuu kuin kauan se kestää, miten pitkä se piikki on." (Kerstin, A1.) Rokotettavat tytöt ovat verrattain nuoria ja terveydenhoitajat pohtivat, kykenevätkö he sisäistämään rokotteeseen liittyviä, aikuisillekin monimutkaisia asioita. Rokote kehystyy terveydenhoitajien mukaan tytöille pistämiseksi, joka jännittää, ja tämä jättää muille jäsennyksille vain vähän tilaa: "tuntuu et se niitten huomio kiinnittyy pelkästään siihen et ne jännittää sitä rokotustilannetta et niitä ei edes kiinnosta et mikä se on se rokote" (Mirva, A1).

HPV-rokote annetaan tiettyjä, seksin välityksellä tarttuvia kohdunkaulansyöpäriskiä nostavia papilloomavirustyyppejä vastaan. Seksi jäi tyttöjen haastatteluissa kuitenkin pieneen rooliin. Tytöt eivät pääsääntöisesti ymmärrä seksin, viruksen ja syövän välisiä yhteyksiä. Silloinkin, kun heillä on jonkinasteinen ymmärrys seksin merkityksestä, liittyy aiheeseen epätietoisuutta, ja virus ja syöpä sekoittuvat keskenään. Pahimmillaan tämä johtaa epäselvään pohdintaan siitä, voiko seksistä saada syövän.

Maria, A2: "Mutta mä en silti oo varma et miten se on mahollista ...ehkä se on sit vaan se virus, joka tulee siitä [seksistä], en tiedä. [...] Sit siin oli ehkä joku sellanen et se voi myös niinku tulla ilmanki sitä [seksiä].”

Kouluterveydenhoitajat ymmärtävät puolestaan viruksen, kohdunkaulan syövän ja seksin välisen yhteyden sekä sen, miksi rokote annetaan juuri 10-12-vuotiaille.

Josefin, A1: ”Tietenkin se on annettu meille tietona, että se annetaan nimenomaan ennen sitä seksuaalidebyyttiä ja suojana papilloomavirusta vastaan ja sen jälkioireita tai jälkitulehduksia ja syöpävaaran minimoimiseks että, et ikänä just semmonen turvallisesti ennen sitä seksuaalista kanssakäymistä.”

Näiden tietojen välittämisen mahdollisuudet ja välittämisen tarkoituksenmukaisuus kuitenkin mietityttävät terveydenhoitajia. Koulujen kiireisessä arjessa ei ole mahdollisuutta perinpohjaiseen 
rokotevalistustyöhön. Luokissa käydään kertomassa tulossa olevasta rokotteesta ja koteihin laitetaan Wilma-palvelun kautta rokottamisesta viestiä, mutta on viime kädessä tyttöjen ja heidän vanhempiensa aktiivisuudesta kiinni, missä määrin rokotteesta lopulta keskustellaan. "Se on aika lailla niin, että Wilman kautta se tieto perheille ja perheet pohtivat, pyydetään tutustumaan näibin linkkeibin" (Seija, A1).

Vaikka rokotteen mekanismi on tytöille pitkälti epäselvä, he tietävät kuitenkin, että rokote annetaan syöpää vastaan. Yleinen ymmärrys syövästä pelottavana sairautena vahvistaa tytöille rokotteen tärkeyttä ja tarpeellisuutta. Vaikka rokotteen täyteen kykyyn estää (kohdunkaulan) syöpää ei uskottaisi, sen ajatellaan vähentävän tulevaisuuden syöpäriskiä. Kyse ei kuitenkaan ole perinpohjaisesta tiedollisesta pohdinnasta vaan varman päälle pelaamisesta ja varuillaan olosta suhteessa vakavaan sairauteen.

Laura, A2: "No en mä usko et sillä on kauheesti mitään vaikutusta, koska en mä usko et kauheen useille tulee mikään se, mikä se on se syöpäjuttu...mutta onhan se hyvä olla silleen varuillaan ni ei tartte ainakaan miettii sitä.”

Myös terveydenhoitajien mukaan syöpä on jäänyt tytöille mieleen.

Karita, A1: ”Kyl ne mun mielestä käyttää sanaa syöpä...ne puhuu siitä syöpärokotteena. Et se ehkäisee syöpää. [...] En mä usko et he välttämättä hahmottaa mikä on papilloomavirus tai että...tietty papilloomavirus...vois aiheuttaa [syöpää].”

HPV-rokotteen kehystyminen syöpärokotteeksi kiinnittyy rokotteen sukupuolittuneisuuteen: rokote annetaan tytöille, koska tytöillä on kohtu, johon voi tulla syöpä. Tyttöjen tiedollinen ymmärrys rokotteesta asettuu tältä osin rokotekampanjan yksinkertaistetun sukupuolittuneeseen kehykseen: kyse on "naisten syöpärokotteesta". Kaikki haastateltavat olivat huomioineet sen, että rokote annetaan ainoastaan tytöille, ja tämä asettuu yleensä pohtimatta kampanjassa korostuvan naisten syövän ja luonnolliseksi ymmärretyn sukupuolieron kehykseen.
Haastattelija: "Muistaksä, mietiksä sitä et miks tytöt vaan saa sen rokotteen vai oliks se vaan et okei?”

Maria, A2: "Siis no, ehkä sen takia että pojilla ei ole kohtua (nauraa)."

HPV-rokotteen sukupuolittunut kehys säilyy, vaikka kohdunkaulan syöpää ei osattaisi nimetä: toisille rokote kehystyy eräänlaiseksi tyttöjen yleiseksi syöpärokotteeksi, osa puolestaan muistaa rokotteen suojaavan esimerkiksi rintasyövältä tai muilta sukupuolittuneilta syöviltä.

Martta, A2: "Eiks se oo rintasyöpään sellain estolää- tai auttaa siihen et se niinku estää rintasyöpää.”

Sukupuolittuneisuus yhdistyy myös erityiseen, tyttöjen omaa ikäryhmää koskevaan kokemukselliseen tapahtumaan. Tässä erityisen tapahtuman kehyksessä sukupuolittuneisuus saa myös voimaannuttavia sävyjä. "Tyttöjen syöpärokote" on heille erityinen, jopa eräänlainen etuoikeus. Tytöt pohtivat tästä näkökulmasta myös pelkästään pojille annettavia rokotteita.

Iida, A2: "Pojat kai saa armeijassa jonkun rokotuksen, niin siitä me puhuttiin. Että niillekin on tulossa siis rokote vähän isompana. Mutta me ei tajuttu et miks tytöille tulee se näin nuorena et miks meille ei tuu sitte vaikka saman ikäsenä kuin pojille.”

Kouluterveydenhoitajille rokotteen sukupuolittuneisuus ei näyttäydy yhtä luonnollistuneena ja lukkoon lyötynä. Yhtäältä he luonnehtivat rokotetta, kampanjaa mukaillen, myönteisessä sävyssä tyttöjen omana, erityisenä juttuna ja kertovat pinkkien kampanjajulisteiden kiinnittäneen tyttöjen huomiota tervetulleella tavalla. Toisaalta he pohtivat kriittisesti stereotyyppiseen tyttöyteen nojaavaa kampanjailmettä, nostavat aktiivisesti esille kysymyksen poikien rokottamisesta ja pohtivat rokotetta monien sukupuolien näkökulmasta. Myös kampanjan lähtökohtaista heteronormatiivisuutta kyseenalaistetaan.

Virve, A1: "Kun on tää monipuoliset sukupuolisuudet, niin...se mietityttää. [...] Ajattelee että joku joka on homo niin ajattelee, että 
no en mä tarviikaan sitä ikinä, koska mä en oo sitten koskaan sukupuoliyhteydes tytön kanssa, et mitä ajatuksia se sitten herättää. [...] Sen vuoksi...mä en tykännyt siitä, et tää oli vaan tällänen, ne jotenkin niin korosti sitä tyttöyttä ja pinkit ne, et se ei jotenkin ei oo ehkä sellasta muutenkaan tätä hetkeä, mitä nää tän hetken nuoret elää.”

Tyttöjen juttu -kampanjassa sukupuolittunut ja voimaannuttava kehys kutsuu tyttöjä tiedolliseen pohdintaan. Kampanjassa keskeinen järkevän rokotetoimijuuden kehys ei kuitenkaan juurru kitkatta tyttöjen elämään. Tietoa on paljon ja sen jäsentäminen koetaan haasteelliseksi.

Maria, A2: "Se [rokotekampanjasivu] oli ehkä vähän hassu, ehkä siitä tehtiin...hirveen niinku iso juttu, emmä tiedä ehkä mä vaan suhtauduin siihen jotenki tosi päivänselvästi mutta...ehkä siitä annettiin jotenki...sellanen et mun pitäs tietää ihan kaikki siitä mutta mulle ois ihan riittäny...että siinä luettais ihan se, että siitä voi tulla jotain sivuoireita ja kaikkee vastaavaa."

Terveydenhoitajat sanovat suoraan, etteivät tytöt heidän mielestään juurikaan tiedä rokotteesta ja sen vaikutusmekanismista eivätkä pohdi rokotetta ylipäänsä tiedollisesti.

Haastattelija: ”Mitä mieltä ootte, mitä...tytöt tietää tästä rokotteesta?”

Seija, A1: "Mä sanoisin, että aika vähän. Silloin varsinkin, kun meille kuului vielä THL:n ohjeen mukaan pitää näitä tämmöisiä rokoteinfoja luokassa, niin mä olin aina niistä etukäteen tiedottanut, jakanut materiaalia ja kehottanut niin vanhempia kuin lapsia tutustumaan siihen Tyttöjen juttu -sivustoon. Ja useasti sit siinä rokotetilanteessa, kun mä kysäisin et hei juttelitteko vanhempien kaa tai ootko käynyt siellä sivulla, niin kyl mä sanoisin että $90 \%$ on silleen et ei. Et ei. Ainakaan ne lapset. Tosi vähän must tuntuu et niillä on tietoa."

Toisin kuin rokotekampanjassa, HPV-rokote ei kehysty tytöille ensisijaisesti tiedolliseksi, järkevän pohdinnan kysymykseksi. Tämä tuottaa haasteita terveydenhoitajille: ensinnäkin tutkitun tiedon välittäminen tytöille on työlästä ja toiseksi tiedon välittäminen on vain yksi työtehtävä monien muiden joukossa kouluterveydenhoidon kiireisessä arjessa. Rokotetiedon välittäminen kehystyy näin ollen osaksi kouluissa tehtävää käytännöllistä terveystyötä, jonka yksi osa on HPV-rokottamisen järjestäminen. Kouluterveydenhoitajat järjestävät koko rokottamisen, rokotteiden tilaamisesta ja tiedottamisesta pistämiseen, kirjaamiseen ja jälkitarkkailuun.

Terveydenhoitajat kohtaavat tyttöjä päivittäin. He pyrkivät ymmärtämään tyttöjen ja heidän perheidensä moninaisuutta, joka tulee esille terveyskysymyksissä. Tästä näkökulmasta tiedollisesti painottuva rokotekampanja näyttäytyy osalle hoitajista liian suoraviivaisena eikä ota perheiden moninaisuutta riittävästi huomioon. Kaija (A1) on erityisen kriittinen:

"Siis jotenki must se THL:n näkemys siitä, et...jotkut ahdasmieliset ihmiset ei haluu tällast seksirokotetta lapsilleen. Niin se on kyllä just semmonen että...emmäkään ehkä luottas semmoseen tahoon...jonka mielestä mä asiakkaana tai äitinä oon lähtökohtasesti väärässä ja mun kulttuuri on ihan väärä ja [...] jos mä oon eri mieltä niin mä oon vaan tyhmä. [...] Must sit on vähän turha ihmetellä et miks ei meiän tarjooma informaatio kelpaa vaan miks uskotaan jotain, just jotain nettipalstoja.”

Kouluterveydenhoitajat tasapainoilevat työssään virallisen terveydenedistämistehtävän toteuttamisen ja oppilaiden kouluarjessa läsnäolevan, kuuntelevan, ymmärtävän ja luotettavan "terkkarin" roolin välillä. He välittävät rokotetietoa, mutta ennen kaikkea huolehtivat rokottamisen konkreettisesta järjestämisestä sekä rakentavat ja ylläpitävät ymmärtävää luottamussuhdetta tyttöihin ja heidän vanhempiinsa.

\section{SOSIAALISET SUHTEET}

Tyttöjen juttu -kampanjassa korostuu yksilöjärkeilyn ohella sukupuolittunut, tyttöjä erityisenä ryhmänä puhutteleva ja voimaannuttava kehys. Tämä kehys on ilmeinen erityisesti kampanjan pinkissä kuvastossa: tytöt tekevät aktiivisesti asioita yhdessä ja heillä on hauskaa tyttöporukassa. Kaikkia oman ikäluokan tyttöjä yhdistävän tapahtuman lisäksi rokote kehystyy haastattelemillemme tytöille kuitenkin myös henkilökohtai- 
sesti määrittyvien sosiaalisten suhteiden kautta. Näistä tärkeimmät ovat suhteet äiteihin, luokkatovereihin ja kouluterveydenhoitajiin.

Kouluterveydenhoitajat kuvaavat toimivansa puolestaan terveyden edistämisen lähettiläinä kouluympäristössä, jonka keskiössä ei ole terveys vaan oppiminen. Toisin kuin monilla muilla terveydenhuollon ammattilaisilla, heillä on arkisessa työssään verrattain vähän vertaiskontakteja. Terveydenhoitajat keskustelevat toki HPV-rokotteesta ja erityisesti rokotuksen järjestämisestä kollegoidensa kanssa. Rokote merkitsee heille rokottamista ja rokottaminen asettuu koulun ja kodin välille muodostuneiden vastavuoroisten luottamussuhteiden kolmioon: kouluterveydenhoitajat-tytöt-vanhemmat, erityisesti äidit.

Titta, A1: "Ideana mun mielestä kouluterveydenhuollossa on se, että me ollaan jotenkin täs arjes mukana, ja mä jotenkin haluun ylläpitää sitä sellasta välitöntä ajatusta ja senpä vuoksi mä just soitan [vanhemmille] aika pienellä kynnyksellä et osoitan, että kun me ollaan kuitenkin täällä...saman verran ku ne lapset on täällä.”

Äitien rooli näyttäytyy tytöille keskeisenä ja usein ratkaisevana. Äidit toimivat kumppaneina rokotetta koskevassa tiedonhaussa ja turvallisina tiedollisina auktoriteetteina. He näyttäytyvät tytöille lähtökohtaisesti oikeina henkilöinä päättämään rokotteen ottamisen kaltaisista terveyskysymyksistä ja heillä on keskeinen rooli myös rokotetiedon jakamisessa. Näin ollen, vaikka tytöt pohtivat rokotetta harvoin tiedollisesti, vahvistavat äidit osaltaan rokotekampanjassa keskeistä järkevän rokotetoimijuuden kehystä: he auttavat tyttöjä käsittelemään luokassa kiertäviä huhuja ja ohjaavat piikkejä jännittäviä tyttöjä valitsemaan syöpäriskiltä suojautumisen ja "varman päälle pelaamisen".

Maria, A2: ”No, kun mä...sanoin, että jotkut meijän luokkalaiset ei ota sitä sen takia, että ne jostain syystä ei tiedä...ei ihan niinku luota siihen, mutta mun äiti sit kerto...et se ois silti niinku ihan hyvä ottaa et...mieluummin otat sen ku syövän (naurahtaa), hyvä varmistua kaikelta."

Luokkatoverien merkitys liittyy rokotteen ottamiskokemukseen ja sen tyttöjä yhdistävään rooliin.
Tyypillisimmillään kyse on vertaistuesta. Keskustelu vertaisten kanssa on yksinkertaisimmillaan tiedonvaihtoa siitä, aiotaanko rokote ottaa. Tytöt pohtivat keskenään myös rokotteen ottamiseen liittyviä haittoja, erityisesti pistoskipua.

Heidi, A2: "Noo, esimerkiks just sitä, että miten se on palautunu se käsi ja sitte että sattuko se paljon tai...ja jos joku ei ollu viel ottanu sitä ni sit niinku osas vähän auttaa sitä siinä [tilanteessa].”

Koko ikäryhmää samanaikaisesti koskettava rokotustapahtuma saattaa myös aiheuttaa epätietoisuutta ja juoruilua luokan sisällä. Luokassa rokotekriittiset näkemykset ja huhut rokotteen ottamisen kivuista ja vakavista haitoista kiertävät helposti. Myös vaihtoehtoisia tapoja suojautua syöpää vastaan nousee esille.

Veera, A2: "Noo, jotain että kun Lilli ja toi Minea, ne oli ainaki meille silleen että, ...jos... joskus saadaan mies ni me käytetään se jossain lääkärissä et jos ne...[on] jonku muun naisen kaa ollu yhessä tai jotain tällästa.”

Myös kouluterveydenhoitajat törmäävät tyttöjen sosiaalisissa verkostoissa kiertäviin huhuihin, joissa esimerkiksi pelotellaan sietämättömällä pistoskivulla. He kuvailevat myös rokottamispäivinä ajoittain ilmenevää "joukkohysteriaa", jossa pistotapahtuma dramatisoituu ja rokotteen pistäminen hankaloituu. Terveydenhoitajat korostavat kuitenkin myös sosiaalisen vertaisuuden tärkeyttä: tytöt toimivat toisilleen tukena paitsi keskusteluissa myös itse rokotustapahtumassa, pitävät kädestä kiinni ja lohduttavat. Vaikka rokotteen kautta nousee esille, miten tärkeitä kaverit ja heidän mielipiteensä 10-12-vuotiaille tytöille ovat, korostuu varsinaisessa rokotuspäätöksessä terveydenhoitajien mukaan kuitenkin kodin rooli. Parhaat kaverit voivat tulla rokotettaviksi siten, että vain toinen heistä ottaa rokotteen ja toinen on ainoastaan tukena. "Tässä se kotona päätetty on se, vahvempi" (Karita, A1).

Tytöille kouluterveydenhoitajat ovat tärkeitä sosiaalisen luottamuksen kautta. Terveydenhoitajat ovat samanaikaisesti tuttuja ja turvallisia aikuisia ja luotettavia terveysauktoriteetteja. Vaikka terveydenhoitajien kanssa ei välttämättä käydä varsinaisia keskusteluja rokotteen taus- 
tasta ja sen ottamisesta, on tytöille tärkeää, että tieto rokotteesta saadaan terveydenhoitajilta ja rokotteet annetaan kouluissa: koulukonteksti kehystää rokotetta luotettavaksi ja turvalliseksi.

Maisa, A2: ”Mä aattelin...kun sitä annetaan niinku kouluissa ja näin ni pakko sen on olla turvallinen.”

Myös kouluterveydenhoitajat korostavat luottamuksen merkitystä. Heille HPV-rokote kehystyy yhdeksi monista (ala)kouluajan terveydenhoidollisista asioista ja työtehtävistä. Näin ollen on tärkeää säilyttää luottamus tyttöihin ja heidän vanhempiinsa - rokottaminen ei saa rapauttaa pitkäkestoista luottamussuhdetta. Vaikka terveydenhoitajat pohtivat rokotteesta kieltäytymisten taustoja, pyrkivät he kuitenkin välttämään kielteisen päätöksen syiden tivaamista. Rokotetta koskevissa keskusteluissa sovitellaan sanat niin, etteivät ne tule tulkituiksi "tuputtamisena"; kunnioitetaan päätöstä ja pyritään säilyttämään vastavuoroinen luottamussuhde.

Kerstin, A1: "Oon halunnut et pysyy hyvä yhteistyö perheeseen. [...] En oo koskaan halunnut lähteä ketään vanhempia vastaan...vaan oon ollut ymmärtäväinen heidän näkemystään kohtaan et jokaisella on oikeus omaan mielipiteeseen ja itse voit tuoda esille ne omat, mut en koskaan oo halunnut lähtee tuputtamaan tai näin. Sit pitää hyväksyä se että, tietysti jokaisella on oikeus olla eri mieltä. Mut sit voi aina keskustella kuitenkin. Semmoista rakentavaa keskustelua."

Terveydenhoitajat kohtaavat myös tyttöjen ja heidän vanhempiensa ristiriitaisia rokotekantoja. Ristiriitatilanteissa pohdittavaksi nousee luottamussuhteiden jakautumisen mahdollisuus. Jos tyttö haluaa rokotteen, mutta vanhempi ei halua hänen sitä ottavan, pyritäänkö vanhemman luottamuksen säilyttämiseen vai luottamuksen säilymiseen ja jopa syventämiseen tytön kanssa? Entä miten jäsentää väestöllisen syöpäterveyden edistämisen ja sosiaalisesti hienosyisenä rakentuvan luottamuksen välistä suhdetta? Vaikka vuonna 2019 päättynyt kirjallinen rokotuslupakäytäntö kuormitti terveydenhoitajien käytännön työtä, selkeytti se heidän mukaansa kuitenkin lupakysymyksiä.
Virve, A1: ”Kun ei enää sitä lupalappua jaeta, niin sit just vähän [mietityttää]...oma oikeusturva tietyllä tavalla...et se oikeesti menee se viesti. Voi luottaa, että ne on saanu sen... ei[kä] tartte sit jälkikäteen...puida sitä, että en olisi halunnutkaan lapselleni. Toki tän ikäinen suurimmaks osaks kyl osaa itekin sanoo, haluaako hän vai ei, että kyllähän sekin täytyis ottaa huomioon, että jos 12-vuotias... itse tulee [että saa] antaa rokottaa, niin kumpi siinä sitten on se päättäjä."

Lupakysymys osoittaa, kuinka tiedolliset ja sosiaaliset, luottamukseen kytkeytyvät ulottuvuudet kietoutuvat yhteen terveydenhoitajien ja tyttöjen sekä heidän vanhempiensa rokotekehystymisissä.

\section{KESKUSTELU}

Terveystieteellisessä HPV-rokotetutkimuksessa korostuu tietävän yksilön lähtökohta. Lähtökohta yhdistyy tavoitteeseen lisätä tietoa ja tiedonjakoa, jotta rokotekampanjat onnistuisivat tuottamaan tavoitteena olevan laumasuojan. Terveyden ja hyvinvoinnin laitoksen tuottamaa Tyttöjen juttu -kampanjaa luonnehtii vastaava järkevän rokotetoimijuuden kehys: tytöille tarjotaan kohdennettua, tutkimuspohjaista tietoa yksilöllisen päätöksenteon tueksi. Tiedon korostus kytkeytyy terveydenhuollossa syvään juurtuneeseen tietoon pohjautuvan suostumuksen periaatteeseen (46). Periaate välittää ristiriitaa yksilöiden itsemääräämisen perusoikeuden (individualismi) ja lääketieteelliselle asiantuntemukselle perustuvan hoitopäätöksen (paternalismi) välillä: yksilö antaa tietoon pohjautuvan suostumuksen itseensä kohdistuvalle, lääketieteellisesti perustellulle toimenpiteelle.

Tietopohjaisen päätöksenteon lähtökohta näyttäytyy tarkastelumme pohjalta kuitenkin yksiulotteisena. HPV-rokote ei kehysty 10-12-vuotiaille tytöille ensisijaisesti tiedolliseksi kysymykseksi eikä heillä ole välttämättä halua tai valmiutta verrattain vaativan rokotetiedon omaksumiseen. Järkevän päätöksen sijaan rokote kehystyy tytöille ennen kaikkea heidän omaa ikäryhmäänsä koskevaksi, sukupuolittuneeksi ja erityiseksi tapahtumaksi, jonka keskiössä on neulalla pistäminen.

Erityinen, sukupuolittunut tapahtuma on läsnä myös virallisessa Tyttöjen juttu -rokotekampanjassa. Kampanjamateriaaleissa tiedollinen, järkevän rokotetoimijuuden kehys yhdistyy suku- 
puolittuneeseen ja tyttöjä voimaannuttavaan kehykseen: pinkki kampanja puhuttelee tyttöjä erityisenä ryhmänä ja kutsuu heitä tiedolliseen pohdintaan. Tyttöjen omissa rokotekehystymisissä asetelma kuitenkin kääntyy ja tiedollinen pohdinta ilmenee pikemminkin uppoutuneena rokotteen sukupuolittuneeseen kehykseen: rokote annetaan vain naisille, naisten syöpää vastaan, ja tytöt pohtivat rokotetta tiedollisesti tämän kehyksen sisällä. Naisten syöpärokotekehys kaventaa samalla tiedollisen pohdinnan alaa. Se piilottaa seksin, papilloomaviruksen ja syövän välisen yhteyden ja näin ollen rokotteen vaikutusmekanismin, joka kohdistuu kaikilla sukupuolilla yleisen, seksiteitse tarttuvan viruksen ehkäisyyn. HPV-rokote on tytöille tyttöjen juttu, koska tytöillä on kohtu, johon voi kehittyä syöpä. Perinpohjaisen punninnan sijasta tyttöjen rokotepohdinnassa korostuu varmuuden vuoksi -ajattelu sukupuolittuneen kehyksen sisällä: naisten syöpää vastaan kannattaa suojautua.

Kouluterveydenhoitajat ovat jatkuvasti läsnä tyttöjen arjessa. Läsnäolo tuottaa ymmärrystä tyttöjen ja heidän perheidensä elämästä sekä rakentaa molemminpuolista luottamusta. Samalla 10-12-vuotiaiden tyttöjen valmius verrattain vaativan rokotetiedon omaksumiseen epäilyttää terveydenhoitajia. Epäily tuo Tyttöjen juttu -kampanjassa keskeisen järkevän rokotetoimijuuden taustan terveydenhoitotyön arkeen. Taustana on yksilön tiedollisen suostumuksen periaate. Rokotetta ja sen taustaa koskeva tieto näyttäytyy tytöille monimutkaisena ja terveydenhoitajat joutuvat pohtimaan sitä, missä vaiheessa kukin tyttö ymmärtää rokotteesta riittävästi ja on näin ollen kykenevä itsenäiseen, tietopohjaiseen päätöksentekoon. Kysymys korostuu nykytilanteessa, sillä vanhemmilta ei enää vaadita kirjallista lupaa lapsensa rokottamiseen.

Tietopohjaisen päätöksenteon kysymys yhdistyy terveydenhoitotyössä kahden eri suuntiin vetävän rokotekehyksen yhteensovittamiseen. Kouluterveydenhoitajat pyrkivät yhtäältä välittämään virallista rokotetietoa tytöille ja heidän vanhemmilleen mahdollisimman tehokkaasti. Toisaalta tyttöjen ja heidän vanhempiensa valmentaminen tietopohjaiseen päätöksentekoon uppoutuu terveydenhoitajien arkeen. HPV-rokote kehystyy kiireisessä arjessa rokottamiseksi, yhdeksi käytännön työtehtäväksi vuosia kestävässä, kotien kanssa yhteistyössä tehtävässä terveystyön jatku- mossa. Tässä kontekstissa rokotteeseen liittyvien kysymysten ei terveydenhoitajien mukaan kannata antaa rapauttaa vastavuoroista luottamussuhdetta tyttöihin ja heidän vanhempiinsa.

Analyysimme haastaa tiedollisen suostumuksen ihannetta HPV-rokotetta koskevassa päätöksenteossa, kun päätösvastuuseen asetetaan rokotteen ottajat itse. Tytöt tekevät rokotepäätöksen omasta merkitysmaailmastaan käsin, ja tiedolliset ulottuvuudet jäävät siinä usein toissijaisiksi. Tyttöjen riittävästä kypsyydestä itsenäiseen HPV-rokotetta koskevaan päätöksentekoon on käyty keskustelua myös Valtakunnallisessa sosiaali- ja terveysalan eettisessä neuvottelukunnassa ja myös eduskunnan oikeusasiamies on ottanut asiaan kantaa (47). Oikeusasiamiehen mukaan tiettyä riittävän kypsyyden ikärajaa ei voida suoraan määritellä. Sen sijaan "ratkaisevaa on, kykeneekö alaikäinen ymmärtämään hoidon tai siitä kieltäytymisen merkityksen ja vaikutuksen terveydentilalleen" (48). Ymmärryksen tason arvioi HPV-rokotteen yhteydessä viime kädessä kouluterveydenhoitaja - keskellä kiireistä arkeaan, terveydenedistämistehtävän ja tyttöjen ja heidän vanhempiensa luottamussuhteiden välisessä ristipaineessa. Tässä kontekstissa tulisi olla selkeämpää, mikä on tytöiltä vaadittava ymmärryksen taso siitä, miten rokote tai siitä kieltäytyminen vaikuttaa terveydentilaan, jotta voidaan katsoa, onko tyttö kykenevä päätöksentekoon.

\section{RAHOITTAJAT:}

Virtanen: tutkimusta ovat rahoittaneet Suomen Akatemian projektit INSPRINS (283447) ja TreWISE (312624) sekä Alfred Kordelinin Säätiö.

Salmivaara: tutkimusta ei ole rahoittanut mikään taho.

\section{KIRJOITTAJIEN KONTRIBUUTIOT:}

Virtanen on vastannut käsikirjoituksen kokonaisuudesta ja kirjoittanut käsikirjoituksen tyttöjen haastatteluaineiston analyysiä lukuun ottamatta. Virtanen on kerännyt ja analysoinut kouluterveydenhoitajien haastattelut sekä taustoittavan aineiston.

Salmivaara on kerännyt ja analysoinut tyttöjen haastatteluaineiston, kirjoittanut tyttöjen haastatteluaineiston analyysin sekä osallistunut muiden osioiden kirjoittamiseen. Salmivaara on hyväksynyt lehteen lähetetyn käsikirjoituksen. 
In this paper, we examine how HPV vaccination is framed as meaningful by Finnish vaccination-aged girls as part of their daily lives and school nurses in their everyday work. We also juxtapose girls' and nurses' framings against each other and trace frictions and continuities between them. Furthermore, we reflect the framings of both groups against the yet established frame of the official campaign, which emphasizes knowledge-based vaccine decision. Our primary data consists of thematic interviews with 21 nurses and 12 girls. As background data, we utilize materials from the official Finnish HPV campaign. We conduct thematic qualitative analysis by utilizing the Goffmanian concept of framings to interpret our data-based findings. In terms of results, we argue that the HPV vaccine is framed primarily as a gendered and cohort-specific event, wherein vaccination-aged girls are pricked with a needle. We suggest that eligible girls do not necessarily have the will, need or capacity to reflect upon the vaccination decision as deliberately as the campaign stresses. Relatedly, the nurses do not merely share the official vaccine information with the girls; instead, they try their bests to manage the tension of conducting the official health work and to maintain trustworthy relationships to the girls and their parents.

Keywords: HPV vaccine, vaccination-aged girls, school nurses, framing, health sociology

$$
\begin{array}{cc}
\text { Saapunut } & 31.03 .2020 \\
\text { Hyväksytty } & 13.07 .2020
\end{array}
$$

\section{LÄHTEET}

(1) Aronowitz, R. Gardasil: a Vaccine against Cancer and a Drug to Reduce Risk. Kirjassa Wailoo K, Livingston J, Epstein, S ym. (toim.) Three Shots at Prevention: The HPV Vaccine and the Politics of Medicine's Simple Solutions. Baltimore: Johns Hopkins University Press; 2010, 21-38.

(2) Terveyden ja hyvinvoinnin laitos. HPV- eli papilloomavirusrokote. Luettu 3.2.2020. https:// thl.fi/fi/web/infektiotaudit-ja-rokotukset/ rokotteet-a-o/hpv-eli-papilloomavirusrokote/

(3) Vänskä S, Söderlund-Strand A, Uhnoo I ym. (2018). Estimating effectiveness of HPV vaccination against HPV infection from postvaccination data in the absence of baseline data. Vaccine 2018;36:3239-3246.

doi: 10.1016/j.vaccine.2018.04.073

(4) Sivelä J, Launis V, Jääskeläinen S ym. Käsitykset rokotuksista ja rokotuskattavuuteen vaikuttavat tekijät. Suomen Lääkärilehti 2018;73:648-652.

(5) Jenkins D, Bosch X. Human Papillomavirus: Proving and Using a Viral Cause for Cancer. Cambridge: Academic Press; 2019.

(6) Zimet GD, Osazuwa-Peters N. There's Much Yet to be Done: Diverse Perspectives on HPV Vaccination. Hum Vaccin Immunother. 2019;15:1459-1464. doi: 10.1080/21645515.2019.1640559.

(7) McRee AL, Reiter PL, Brewer NT. Vaccinating adolescent girls against human papillomavirus -Who decides? Prev Med 2010;50:213-214.
(8) McRee AL, Reiter PL, Gottlieb SL ym. Motherdaughter communication about HPV vaccine. J Adolesc Health 2011;48:314-317.

(9) Ward JK, Crépin L, Banquier C ym. 'I don't know if I'm making the right decision': French mothers and HPV vaccination in a context of controversy. Health Risk Soc 2017;19:38-57. doi: 10.1080/13698575.2017.1299856

(10) Karafillakis E, Simas C, Jarrett C ym. HPV vaccination in a context of public mistrust and uncertainty: a systematic literature review of determinants of HPV vaccine hesitancy in Europe. Hum Vaccin Immunother 2019;15:1615-1627. doi: 10.1080/21645515.2018.1564436

(11) Hilton S, Smith E. "I thought cancer was one of those random things. I didn't know cancer could be caught...": adolescent girls' understandings and experiences of the HPV programme in the UK. Vaccine 2011;29:4409-4415. doi: 10.1016/j.vaccine.2011.03.101

(12) Davies C, Skinner SR, Stoney T ym. 'Is it like one of those infectious kind of things?' The importance of educating young people about HPV and HPV vaccination at school. Sex Educ 2017;17(3):256-275. doi: 10.1080/14681811.2017.1300770.

(13) Rosen BL, Bishop JM, McDonald S ym. Factors Associated with College Women's Personal and Parental Decisions to be Vaccinated Against HPV. J Community Health 2018;43:1228-1234. doi: 10.1007/s10900-018-0543-8. 
(14) Zimet GD, Rosberger Z, Fisher WA ym. Beliefs, behaviors and HPV vaccine: correcting the myths and the misinformation. Prev Med 2013;57:414 418.

(15) Hendry M, Lewis R, Clements A ym. "HPV? Never heard of it!": a systematic review of girls' and parents' information needs, views and preferences about human papillomavirus vaccination, Vaccine 2013;31:5152- 5167.

(16) Waller J, Forster AS, Ryan, M. Decision-making about HPV vaccination in parents of boys and girls: A population-based survey in England and Wales. Vaccine 2020;38:1040-1047. doi: 10.1016/j.vaccine.2019.11.046

(17) Rosen BL, DiClemente R, Shepard AL ym. Factors associated with school nurses' HPV vaccine attitudes for school-aged youth. Psychol Health Med 2017;22:535-545. doi: 10.1080/13548506.2016.1173710

(18) Grandahl M, Larsson M, Tydén T ym. School nurses' attitudes towards and experiences of the Swedish school-based HPV vaccination programme - A repeated cross sectional study. PLoS One 2017;18:e0175883. doi: 10.1371/journal.pone.0175883

(19) Rockliffe L, McBride E, Heffernan C ym. Factors Affecting Delivery of the HPV Vaccination: A Focus Group Study with NHS School-Aged Vaccination Teams in London. J Sch Nurs 2018;5:1059840518792078. doi: 10.1177/1059840518792078

(20) Hilton S, Hunt K, Bedford H, Petticrew M. School nurses' experiences of delivering the UK $\mathrm{HPV}$ vaccination programme in its first year. BMC Infect Dis 2011;11:226. doi: 10.1186/1471-2334-11-226.

(21) Gilkey MB, Calo WA, Moss JL ym. Provider communication and HPV vaccination: The impact of recommendation quality. Vaccine 2016;34:1187-1192. doi: 10.1016/j.vaccine.2016.01.023

(22) Davies C, Skinner SR, Stoney T ym. 'Is it like one of those infectious kind of things?' The importance of educating young people about HPV and HPV vaccination at school Sex Educ 2017;17:256-275. doi: 10.1080/14681811.2017.1300770

(23) Hudson SM, Rondinelli J, Glenn BA ym. Human papillomavirus vaccine series completion: Qualitative information from providers within an integrated healthcare organization. Vaccine 2016;34:3515-3521. doi: 10.1016/j.vaccine.2016.02.066

(24) Wynne B. Knowledges in context. Sci Technol Hum Values 1991;16:111-121.

(25) Gottlieb SD. Vaccine resistances reconsidered: Vaccine skeptics and the Jenny McCarthy effect. Biosocieties 2016;11:152-174. doi: 10.1057/biosoc.2015.30

(26) Casper MJ, Carpenter LM. Sex, drugs, and politics: the HPV vaccine for cervical cancer, Soci Health Illn 2008;30:886-899.
(27) Paul KT. Saving lives: adapting and adopting Human Papilloma Virus (HPV) vaccination in Austria. Soc Sc Med 2016;153:193-200.

(28) Paul KT, Wallenberg I, Bal R. Putting public health infrastructures to the test: introducing HPV vaccination in Austria and the Netherlands. Sociol Health Illn 2018;40:67-81. doi: 10.1111/1467-9566.12595

(29) Maldonado Castañeda OJ. (Un)contested evidence: scientific literature, systematic reviews and the politics of evidence in the introduction of HPV vaccines in Colombia. Sociol Health Illn 2019;41:81-94. doi: 10.1111/1467-9566.12808.

(30) Gottlieb SD. Not Quite a Cancer Vaccine: Selling HPV and Cervical Cancer. New Brunswick: Rutgers University Press; 2018.

(31) Lindén L. Communicating Care: The Contradictions of HPV Campaigns. Lund: Arkiv Academic Press; 2016.

(32) Albert K. Beyond the responsibility binary: analysing maternal responsibility in the human papillomavirus vaccination decision. Sociol Health Illn 2019;41:1088-1103. doi: 10.1111/1467-9566.12887

(33) Connell E, Hunt A. The HPV vaccination campaign: a project of moral regulation in an era of biopolitics. Can J Soc 2010;35:63-82.

(34) Mamo L, Nelson A, Clark, A. Producing and Protecting Risky Girlhoods. Kirjassa Wailoo K, Livingston J, Epstein, S ym. (toim.) Three Shots at Prevention: The HPV Vaccine and the Politics of Medicine's Simple Solutions. Baltimore: Johns Hopkins Univ Press; 2010, 121-145.

(34) Rail G, Molino L, Fusco C ym. HPV vaccination discourses and the construction of "at-risk" girls. Can J Public Health 2018;109:622-632. doi: 10.17269/s41997-018-0108-8.

(35) Mamo L, Epstein S. The pharmaceuticalization of sexual risks: vaccine development and the new politics of cancer prevention. Soc Sc Med 2014;101:155-165.

(36) Johnson E (toim.) Gendering Drugs: Feminist Studies of Pharmaceuticals. Basingstoke: Palgrave Macmillian; 2017.

(37) Mara M. Spreading the (dis)ease: Gardasil and the gendering of HPV. Fem Form 2010;22:124 143.

(38) Polzer JC, Knabe SM. From desire to disease: human papillomavirus (HPV) and the medicalization of nascent female sexuality. J Sex Res 2012;49:344-352. doi: 10.1080/00224499.2011.644598.

(39) Mishra A, Graham JE. Risk, choice and the 'girl vaccine': unpacking human papillomavirus (HPV) immunization. Health Risk Soc 2012;14:57-69.

(40) Vardeman-Winter, J. Medicalization and Teen Girls' Bodies in the Gardasil Cervical Cancer Vaccine Campaign. Fem Media Stud 2012;12:281-304. 
(41) Silvast, A, Virtanen, MJ. An assemblage of framings and tamings: multi-sited analysis of infrastructures as a methodology.

J Cult Econ 2019;12:461-477. doi: 10.1080/17530350.2019.1646156.

(42) Virtanen, MJ, Silvast, A. Monipaikkainen kehystymistutkimus. Sosiologia 2020;57:183202.

(43) Gofmann, E. Frame Analysis: An Essay on the Organization of Experience. Cambridge, MA: Harvard University Press; 1974.

(44) Virtanen, MJ. What kind of 'a girls' thing'? Frictions and continuities in the framing and taming of the HPV vaccine in Finland 2019; 41:789-805. doi: $10.1111 / 1467-9566.12853$

(45) Corbin J, Strauss, A. Basics of Qualitative Research (4th ed.): Techniques and Procedures for Developing Grounded Theory. London: Sage; 2012.
(46) Faden RR, Beauchamp TL. A History and Theory of Informed Consent. New York: Oxford University Press; 1986.

(47) Virtanen, MJ. Moniäänisyyden ja tahdikkuuden välissä: eettisyys ETENEn neuvottelukuntatyössä. Tiede \& edistys 2018;43:306-325.

(48) Oikeusasiamiehen päätös 11.6.2015 (Dnro 5294/2/13) "HPV-ROKOTUSKAMPANJAN TOIMEENPANO" (ei sivunumeroita).

\author{
Mikko J. VirTANEN \\ VTT, tutkijatohtori \\ Tampereen yliopisto \\ Yhteiskuntatieteiden tiedekunta (SOC)
}

SAARA SALMIVAARA

YTM, tutkija

Helsingin yliopisto

Valtiotieteellinen tiedekunta 